\title{
Horticultural biotechnology faces significant economic and market barriers
}

Julian M. Alston

$\nabla$

\section{Technological change has driven} economic progress in agriculture and will continue to play a crucial role in the 21st century. The latest wave of technological change in agriculture is based in molecular biology. Will horticulture participate? Genetically engineered crop varieties have been adopted on a wide scale in some agronomic crops, but horticultural crops face larger hurdles. High costs for research, development and regulatory approval combined with the small acreages planted and the diversity of varieties, will limit the potential for profitable applications of biotechnology to many fruits and vegetables, tree fruits and nuts, and nursery crops. In addition, there are market barriers. Like most important changes in agriculture, modern biotechnology has met with spirited political opposition from some quarters. Threats of political action may discourage food manufacturers and retailers from adopting biotech products that are wanted by some consumers and may be profitable for growers.

\footnotetext{
griculture has been an important Aengine of economic development, and the mainspring of economic progress in agriculture has been productivity improvements driven by technological change that is fueled by research and development (R\&D). Since World War II, agricultural productivity has more than doubled in the United States, as in many other countries. California agriculture today produces more than twice the output of 1950, using roughly the same total input - although with less labor and land, and more capital and purchased inputs.
}

These gains can be attributed to new biological, mechanical and chemical technologies, including improved genetic material, machines, fertilizers and pesticides, and knowledge. The current wave of technological progress continues this pattern, while emphasizing information technologies and biotechnology - in particular genetically modified (GM) crops. For many, GM crops represent the hope for a future with less hunger and malnutrition, and for a more sustainable agriculture with more varied, cheaper and safer food. For others they are cause for serious concern about the environment and food safety. Regardless of how we may feel about it, the juggernaut of technological change continues and the biotechnology revolution is well under way in the United States and other countries.

The challenge for public policy is to determine what regulations should be applied to govern the development and use of these technologies, and what other types of intervention may be necessary, such as public investments in research to correct for private-sector underinvestment. In the case of horticulture - the cultivation of fruits and vegetables, tree fruits and nuts, turfgrass, flowers and ornamental crops these issues are sharply drawn because the private sector has not found it profitable to develop or commercialize many GM crops in the current political, legal and market environment.

What will happen in biotechnology applied to horticultural crops is up to the government, for a variety of economic reasons. Some of these aspects may be unique to GM horticultural crops but many are common to GM crops generally, and similar issues arise with some new non-GM technologies.

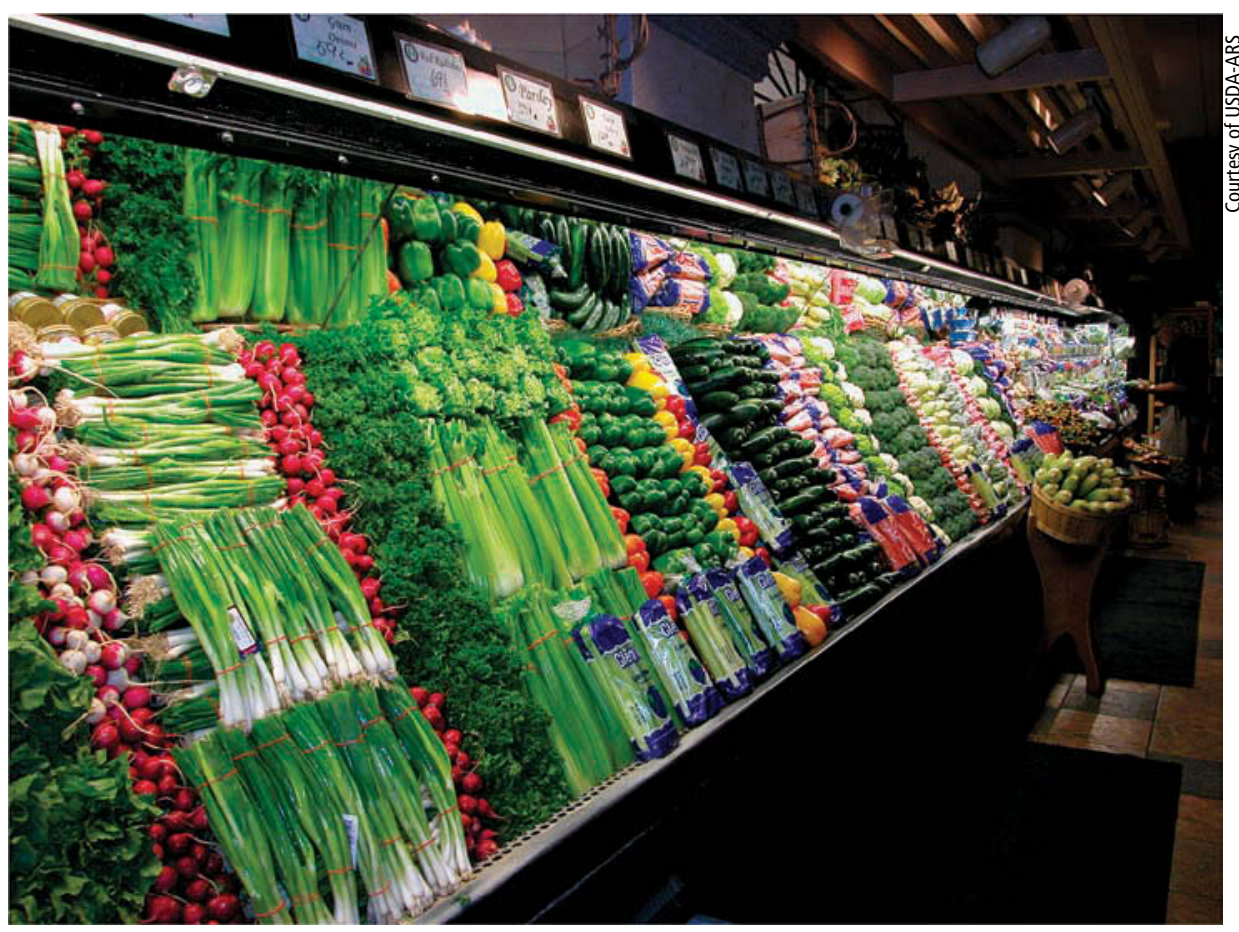

While agricultural biotechnology has revolutionized agronomic crops such as soybeans, corn and cotton in the United States, thus far virtually none of the produce on supermarket shelves is genetically engineered. The reasons for this disparity are complex. 
For many, [transgenic] crops represent the hope for a future with less hunger and malnutrition, and for a more sustainable agriculture with more varied, cheaper and safer food. For others they are cause for serious concern about the environment and food safety.

\section{Public, private roles in ag science}

Without government intervention, the rate of innovation will be too slow, reflecting both underinvestment in research and underadoption of some research results. Both problems are related to the nature of property rights for research results. "Free-rider problems" occur when property rights are incomplete, and private investors can capture only part of the returns to their investments in certain types of research (such as developing new crop varieties); as a result, their incentives to invest are reduced. On the other hand, when the rights to research results are protected, such as by patents or trade secrets, the owner of a new variety can charge monopoly prices, unduly limiting the use of that variety. Intellectual property rights (IPRs) are a double-edged sword: to the extent that they provide a greater incentive for investing in research they are also likely to result in lower adoption rates.

Governments have addressed the incentive problems in agricultural research in several ways. Federal and state governments (as well as industry) have funded agricultural research at public institutions such as the U.S. Department of Agriculture (USDA) and state agricultural experiment stations associated with land-grant colleges. This approach allows an increase in total research without the problems associated with monopoly pricing of inventions. However, even though the investment has paid handsome dividends, it is increasingly difficult to sustain the past levels of funding for public agricultural $R \& D$, in the face of general budget problems and declining political support for public science funding, including agricultural science (Alston et al. 2000). Governments have also acted to strengthen IPRs applied to plants and animals as well as mechanical technologies; and changes in IPRs, especially in the 1980s, were crucial for the agricultural bio-

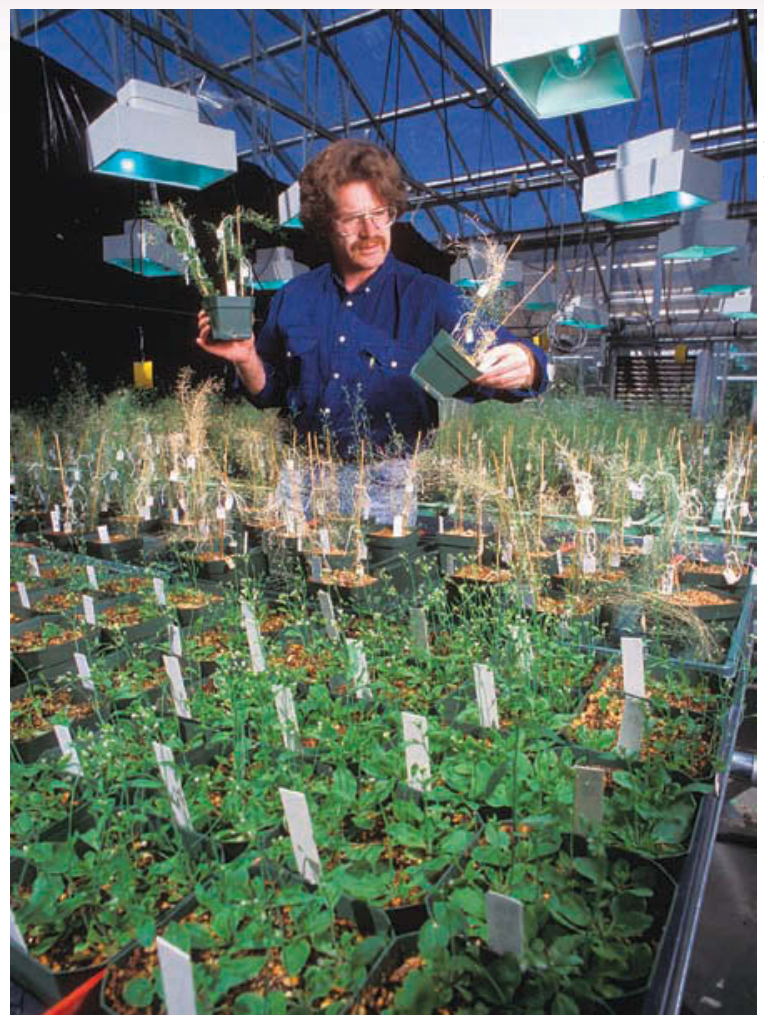

Large corporations have found it profitable to invest in research on genetically engineered agronomic crops, but smaller firms and public institutions such as the U.S. Department of Agriculture and land-grant universities undertake much of the research on horticultural crops. Above, Peter Quail of UC Berkeley inspects mutant Arabidopsis plants at the Plant Gene Expression Center, a joint venture of UC and USDA in Albany, Calif.

technology development that followed. Partly as a reflection of enhanced IPRs, in the United States, private-sector funding of agricultural research has been growing faster than public-sector funding and now exceeds it.

The balance in agricultural R\&D between the private and public sectors varies among types of research. For instance, until recently the private sector emphasized agricultural R\&D pertaining to mechanical and chemical technologies, especially pesticides, where IPRs are effective; and the government was more important in other areas such as improving crop varieties. Private involvement was dominant in cropvariety research only in hybrid corn, where the returns were well protected by technical restrictions on copying or reusing saved seed, trade secrets and other legal rights. Changes in the institutional environment and the form of new IPRs, combined with new scientific possibilities associated with modern biotechnology, resulted in a shift in the private-public balance in research to improve crop varieties. As the balance shifts toward private research, new attention must be paid to old questions about whether the private investment in crop research will be sufficient, whether the allocation of those resources (say, among crops) will be optimal, whether the results will be adopted rapidly and widely, and what role the government should play.

\section{Economic and market aspects}

The development of new technologies through R\&D is only one element of the picture. The technologies must also be approved for commercial application and economically attractive enough to be adopted by farmers. The experience with other biotech crops has lessons for horticultural biotechnology.

Biotech crops have been a commercial reality only for a few years but they have made very rapid inroads in some parts of the market. In particular, pest-resistant and herbicidetolerant corn, soybeans, canola and cotton were rapidly developed and adopted in the United States and to a lesser extent in other countries (James 2000). To date, the successful GM crop varieties have emphasized "input traits," related to reducing the use of chemical pesticides or making them more effective, rather than "output traits," related to product quality. Why has there been rapid development and adoption of GM cropping technologies for these crops and not other important crops, such as wheat and rice? The likely reasons relate to the nature of supply and demand for new technology, and the economics of adoption.

- continued on page 84 


\section{Transgenic produce slow to enter evolving global marketplace}

\author{
Roberta L. Cook
}

IF and when genetically engineered (GE) horticultural products become more widely available and adopted, they will enter an expanding marketplace that is becoming globally integrated and more consolidated. Fewer, larger firms will control access to a rising share of the world's population, including rapidly growing middle-income consumers in the developing world. Consumers everywhere will be increasingly focused on convenient, ready-to-eat and value-added products. In order to compete on a global scale, GE produce must meet the challenges of the quickly evolving market for fruits and vegetables.

In the United States alone, the estimated final value of fresh produce sold through retail and food-service channels surpassed $\$ 81$ billion in 2002. Europe-wide fresh produce sales through supermarket channels alone (excluding green grocers and food service) were estimated to exceed $\$ 73$ billion in 2002, and total final sales to exceed $\$ 100$ billion.

Worldwide, consumption and cultivation of fruits and vegetables is increasing. Between 1990 and 2002, global fruit and vegetable production grew from 0.89 billion tons to 1.3 billion tons, and per capita availability expanded from 342 pounds to 426 pounds (FAO 2003). Much of this growth has occurred in China, which is aggressively pursuing agricultural biotechnology (see page 112).

The global fresh fruit-and-vegetable marketing system is increasingly focused on adding value and decreasing costs by streamlining distribution and understanding customer demands. In the United States and Europe this dynamic system has evolved toward predominantly direct sales from shippers to supermarket chains, reducing the use of intermediaries. Food-service channels (hotels, restaurants and institutions) are absorbing a growing share of total food volume and are also developing more direct buying practices. The year-round availability of fresh produce is now seen as a necessity by both food service and retail buyers.

Product form and packaging are also changing as more firms introduce valueadded products, such as fresh-cut produce, salad greens and related products in consumer-ready packages. Estimated U.S. sales of fresh-cut produce were over $\$ 12$ billion in 2002. Fresh-cut sales are even higher in Europe and beginning to develop in Latin America and Asia as well. The implications of this trend may become as important to the biotechnology industry as the changes in market structure, since fresh-cut processors are increasingly demanding specific varieties bred with attributes beneficial to processing quality.

\section{International trade}

The streamlining of marketing channels poses both challenges and opportunities for horticultural biotechnology. A smaller number of larger firms, controlling more of world food volume, now act as food-safety gatekeepers for their consumers, reflecting the diversity of consumer preferences in their buying practices. Where consumers perceive products utilizing biotechnology to be beneficial, retail and food-service firms will provide them. Products with specialized input traits valued by consumers, such as unique color, flavor, size or extended shelf-life, are the most likely to succeed in today's marketplace.

While large food-service and retail buying firms and international traders may offer easy access to consumer markets, if major buyers adopt policies unfavorable to GE foods, distribution obstacles could become insurmountable. Such policies are common among European food retailers, reflecting strong consumer concern there over GE products.

The challenge to supply seasonal, perishable products year-round has favored imports, and increased horizontal and vertical coordination and integra- tion among shippers regionally, nationally and internationally. Seasonality in the production and consumption of perishable commodities, due to natural climatic conditions, causes much horticultural trade to be counter-seasonal, such as the shipment of Southern Hemisphere grapes and stone fruits from Chile to the United States and Europe in order to meet consumer demand during the Northern Hemisphere's winter, when domestic supplies are low.

Integration among international traders and grower-shippers allows them to position themselves as consistent year-round suppliers of differentiated products; these firms increasingly seek out varieties that offer superior

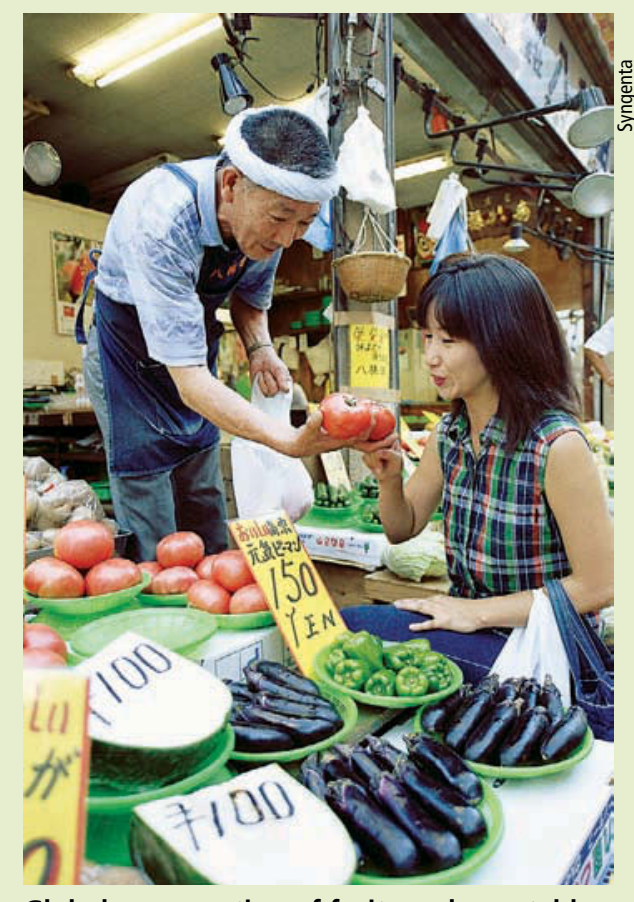

Global consumption of fruits and vegetables is on the rise, but important markets for California produce growers such as Europe and Japan, above, have taken a cautious approach toward imports of transgenic foods.

flavor and other attributes. For example, Sun-World, a California fresh fruit shipper is pursuing a strategy of marketing differentiated, proprietary varieties where possible. These varieties must be provided from multiple locations in the Northern and Southern Hemispheres so that shippers can provide customers around the world with a year-round supply of consistent quality. Long-term, breeding a set of attributes into a particular fruit or veg- 
etable variety in one location will be insufficient to meet these goals.

The United States is the world's largest importer and exporter of fruits and vegetables. U.S. imports of fruits and vegetables grew from $\$ 6.7$ billion in 1990 to $\$ 10.8$ billion in 2001, while imports by E.U. countries (including intra-E.U. trade) grew slightly to about $\$ 36$ billion. Germany has long been the most important import market within Europe, accounting for $12 \%$ of world fruit and vegetable imports in 2001. However, a declining import share for Germany is largely responsible for a drop in the E.U.'s share of world imports from $56 \%$ in 1990 to $48 \%$ in 2001. Japan imported $\$ 5.9$ billion worth of fruits and vegetables in 2001, accounting for about $8 \%$ of world imports since 1993.

While the influence of the European Union and Japan on world horticultural markets has not been growing, they will remain vitally important. Leading and emerging fruit and vegetable suppliers will continue to vie for these lucrative markets and will respond to market signals conveying evolving European and Japanese preferences regarding the use of biotechnology. Furthermore, in the case of Japan, declining domestic horticultural production over time and economic recovery are expected to eventually cause imports to rebound.

The importance to the United States of European and Japanese preferences regarding GE foods is evident. In 2001, the United States exported $\$ 1.1$ billion of fresh and processed fruit, vegetables and nuts to the European Union and had a \$300 million trade surplus with the European Union in these products (USDA 2002). Nuts, raisins and fruit juices are most important, with about two-thirds of the trade in those categories, while fruits such as table grapes, stone fruit and citrus are also important. In 2001, the United States also shipped fresh fruit worth $\$ 537$ million to Japan, accounting for $40 \%$ of the market (USDA 2003). On the other hand, the United States is now a minor player in the Japanese vegetable import market, shipping \$278.3 million worth of vegetables in 2001, a 14\% share. China has become the leading (and still growing) supplier of fresh vegetables to Japan, with a 57\% share. Hence, Japanese consumer preferences regarding GE foods will affect the U.S. fruit industry more than the vegetable industry.

Countries well known for their fruit exports, such as Chile, Brazil, Argentina and Ecuador, have market shares of $2.3 \%$ or less, and Australia and New Zealand hover at the $1 \%$ level. While some countries may hold important market shares in certain individual products, in general, there is still great geographic diversification in the world fruit and vegetable trade. For fresh vegetables, the world's top five exporters (the Netherlands, Spain, Mexico, United States and China) contributed the latter half of the 20th century in the United States and Europe.

With store locations in 10 countries, Wal-Mart is the one U.S. firm with a global presence, and it is also the world's largest grocery retailer. Approximately 30\% of Wal-Mart's \$259 billion in global 2003 sales were estimated as grocery-equivalent, generating impressive new buying power in the food industry. To date, Wal-Mart's policy is to market GE food products.

As the food distribution system consolidates, retailers are seeking larger suppliers that come closer to matching their scale, as well as suppliers offering more services and marketing support, tailored to their specific needs. This

\section{With store locations in 10 countries, Wal-Mart is the one U.S. firm with a global presence, and it is also the world's largest grocery retailer.}

$59 \%$ of total export value in 2001 . Only the United States was ranked within the top five both as an importer and exporter, making decisions in the United States regarding biotechnology especially important to vegetable breeders.

\section{Retail markets}

Over the past decade the world has experienced a high rate of mergers and acquisitions in the grocery retailing industry, both in home country markets and across borders via foreign direct investment. Over the past decade this trend led to an estimated 30 firms accounting for $10 \%$ of global grocery sales (M+M PlanetRetail 2003). Many of these chains are European and Asian, but with store locations in numerous countries, enhancing their global buying power.

Latin America and Asia have experienced striking growth in the role of supermarkets in food retailing over the past decade, with southern and eastern Africa engaged in the same transformation process (Weatherspoon and Reardon 2003). Over the next decade the rapid evolution of supermarkets should induce more direct linkages between suppliers and retailers on a global scale, gradually eroding the dominant role of traditional wholesalers, open street markets and small-scale fruit and vegetable vendors, following the trend occurring in movement toward account-based marketing is making the food system more technology-intensive, including the introduction of demand-based information management practices to stimulate sales and profits for retailers. To compete effectively, both suppliers and buyers must be consumer-driven, utilizing modern information management practices in all aspects of the vertical food system. The adoption (or not) of GE foods will depend on consumer response as measured by commercial buyers acting as food safety gatekeepers.

\section{R.L. Cook is Extension Marketing}

Economist, Department of Agricultural and Resource Economics, UC Davis.

\section{References}

[FAO] Food and Agricultural Organization. March 2003.United Nations. www.fao. org.

M+M PlanetRetail. 2003. www.planetretail.net.

[USDA] U.S. Department of Agriculture. 2002. Gain Report \#E22104. European Union trade data - multiple commodities only - fruit and vegetables - CY 2001 statistics. Nov. 6. Foreign Agricultural Service, Washington, DC.

[USDA] U.S. Department of Agriculture. 2003. GAIN Report \#JA3701. Market brief for Japanese food processing sector. Feb. 20. Foreign Agricultural Service, Washington, DC. Weatherspoon D, Reardon T. 2003 (May). Development Policy Rev: 21(3). 
Benefits to farmers and others. The total benefits from farmers adopting any new cropping technology are approximately equal to the benefits per acre times the number of acres affected. With pest-resistant crop varieties, these benefits come primarily from reduced costs for applying chemical pesticides and increased yields, after an allowance for regulatory requirements for refugia to manage resistance. The distribution of these total benefits between farmers (and ultimately food and fiber consumers) on the one hand, and the technology suppliers on the other, is determined by the size of the premium charged for the use of the new technology, but this premium also affects the incentives for farmers to adopt the technology.

Economic studies suggest that farmers and biotech companies have shared in the benefits of biotech crops and that the net benefits have been large. Gianessi et al. (2002) conducted 40 detailed U.S. case studies of biotech cultivars. They estimated that in 2001, eight biotech cultivars adopted by U.S. growers provided a net value of $\$ 1.5$ billion to growers, reflecting increased crop values and cost savings. They further estimated that the 32 other case-study cultivars would have generated an additional $\$ 1$ billion in benefits to growers if they had been adopted, bringing the total potential benefit in 2001 to $\$ 2.5$ billion. Of this annual total, the lion's share was for herbicide-tolerant crops ( $\$ 1.5$ billion per year), followed by insect-resistant crops (\$370 million per year). These estimates do not represent the total economic impact because the geographic analysis was limited in scope, and they do not include any benefits to the seed companies and biotech firms that produced the technology.

Environmental concerns. Private benefits and costs from biotech crops accrue to growers and consumers of the products, along with seed companies and biotech firms. If the new technology involves environmental risks (as some fear may be the case with biotech crops) or replaces technology that involves environmental risks, there will

\section{Diversity of horticultural biotech crops contributes to market hurdles}

\author{
Kent J. Bradford \\ Julian M. Alston
}

W hy is the acreage of biotech agronomic crops continuing to increase while commercialization of horticultural biotech products stagnates? Representatives of the horticultural industry offered a variety of explanations at a workshop in Monterey in March 2002 (see acknowledgments below).

Species diversity. Virtually all of the biotech crops currently grown are in four species (soybean, corn, cotton and canola). This contrasts with the hundreds of horticultural species and thousands of fruit, vegetable and ornamental crop varieties. In most cases, specific procedures are required to genetically transform each species, and the ease with which different varieties can be transformed varies widely. Introducing a trait into a specific crop and variety may require considerable research and development. The diversity of propagation and marketing mechanisms also presents challenges, as many horticultural crops are veg- varieties - even if the product, such as broccoli, appears virtually identical - to assure availability in the market every day of the year. Consumers often prefer different colors of their favorite flower. Introducing a trait into a horticultural species likely requires its introduction into multiple varieties to achieve market success.

Limited market windows. The niche market for horticultural crops also means that any single variety is likely to be successful in only a small fraction of the crop's total market. In California lettuce production, a given variety may have a market window of only a few weeks in a specific location as production moves seasonally around the state. The potential acreage (and sales) of a variety is limited, and unless development and regulatory costs can be spread over multiple varieties, the potential returns on a biotech trait are often too small to be economically feasible (see page 106).

\section{Many processed products are marketed internationally and regulatory approval is required in each importing country, possibly with each having different testing or labeling requirements.}

etatively propagated from cuttings or grafting rather than by seed, or are perennial, bringing different issues for containment, stewardship and value.

Multiple niche markets. Unlike the commodity agronomic crops, horticultural markets are highly segmented by factors such as location, season and consumer preferences. The horticultural market is composed of many niche markets, and any single product may be successful in just a few of those niches. People in different countries or regions prefer different colors, shapes, sizes and flavors of melons, for example. Diseases vary by location, so the types of resistant varieties required also vary. Diverse growing conditions and seasons require multiple adapted
Processor requirements. For most processed crops, the processor specifies the varieties grown and the raw-product standards. While existing biotech traits would be beneficial to processors, such as high viscosity in tomatoes or insect resistance in sweet corn, processors are also highly sensitive to consumer preferences and often have recognizable brand names that are much more valuable than any single product. Processors are wary of jeopardizing their overall market position by risking pickets or protests from anti-biotech activists. For example, Dole would have little interest in helping its lettuce growers control weeds with herbicide-tolerant lettuce if that would put its global pineapple and banana markets at risk. 

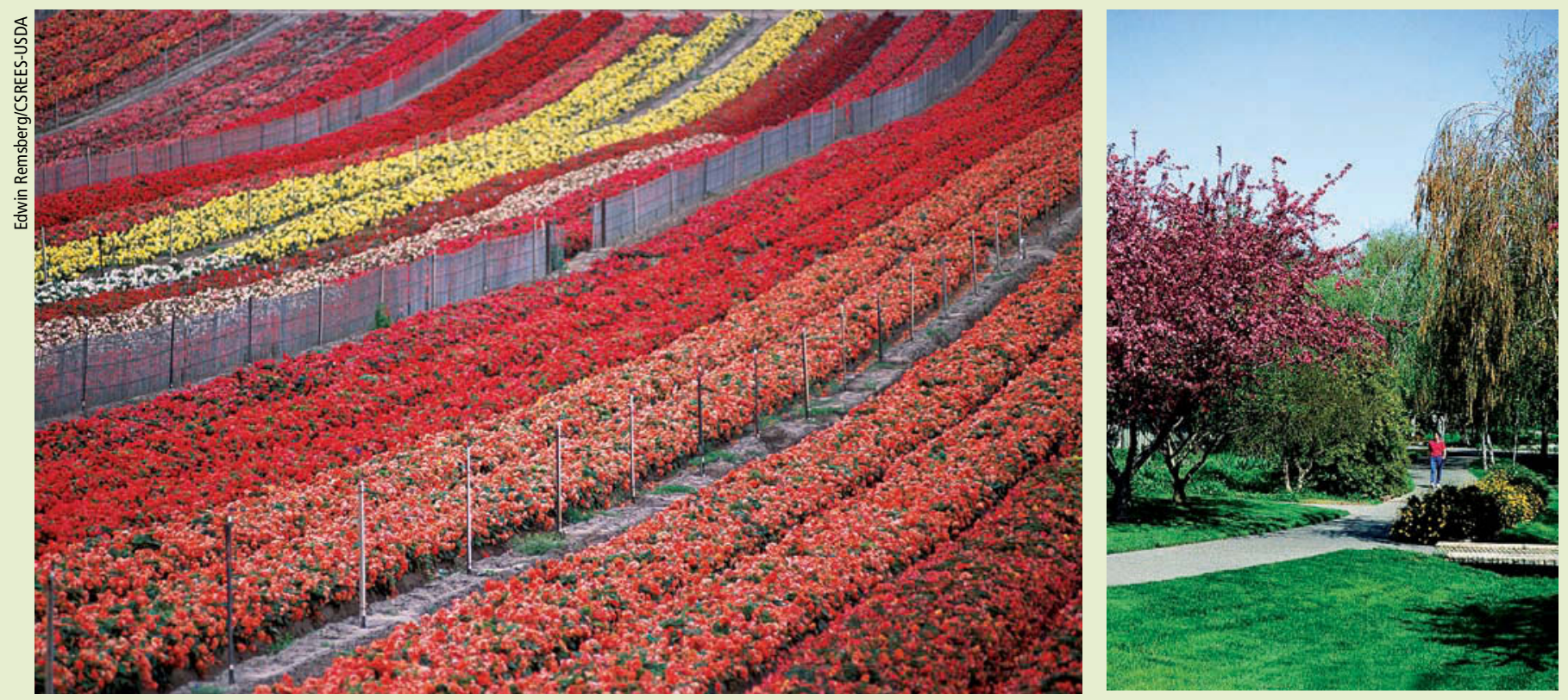

With regard to horticultural crops, consumer preferences vary. They may want several different melon varieties or flower colors, left. Garden and lawn-care products such as turfgrass, right, could provide inroads for genetically engineered varieties.

In addition, many processed products are marketed internationally and regulatory approval is required in each importing country, possibly with each having different testing or labeling requirements. Segregating or channeling processed products for different markets is possible, but requires extensive (and expensive) changes in current production and distribution systems.

Distribution requirements. The distribution and retailing of horticultural products is increasingly global and concentrated (see page 82). Large distribution firms can dictate standards independent of any regulatory system, so whether they agree to market a particular product can mean the difference between success and failure. Labeling on the basis of whether recombinant DNA techniques were used is not required in the United States, but it is in many other countries. There is still no consistency among countries about what should be on such a label, how much information it should provide or whether it should be voluntary or mandatory.

Traceability is the ability to track a product from the market back to the field or greenhouse where it was produced. While this is possible with some items, such as fresh flowers, fruits and vegetables, it is more difficult with products commingled during processing such as canned vegetables and fruits. Segregation of products is pos- sible, as for organic foods, but associated costs often require higher prices for profitability.

Liability is a critical issue, as demonstrated by recalls following the discovery of Starlink corn in tortilla chips, when the transgenic variety had not been approved for human consumption. The food industry is leery of any situation where its products might be considered adulterated and require a recall. Without practical thresholds for adventitious (unexpected or accidental) presence of biotech DNA or protein in the processed product (as there are for things like insects found in agricultural products), the risk is high with little benefit to the distributor.

Consumer benefits. While the first wave of biotech products was targeted primarily to growers, incentives are needed throughout the marketing chain to share both the risks and the benefits. Products with clear benefits for consumers may be needed to develop demand; these will also likely require a premium price to compensate for the tracking and segregation needed to ensure that the promised quality is delivered. As biotechnology moves beyond the initial phase of input traits and begins to develop output and consumer traits, its developers must pay attention to the interests, concerns and requirements of all participants in the production, processing, distribution and marketing chain.
K.J. Bradford is Director, Seed Biotechnology Center, and Professor, Department of Vegetable Crops, UC Davis; and J.M. Alston is Professor, Department of Agricultural and Resource Economics, UC Davis, and Associate Director, UC Agricultural Issues Center.

"The Workshop on Biotechnology for Horticultural Crops: Challenges and Opportunities," held in Monterey in March 2002, was sponsored by the Giannini Foundation, UC BioStar Project, UC Davis College of Agricultural and Environmental Sciences, UC Division of Agriculture and Natural Resources, UC Agricultural Issues Center and UC Davis Seed Biotechnology Center. Presenters included Ted Batkin (California Commodities Committee and Citrus Research Board), Fred Bliss (Seminis Vegetable Seeds), Neal Gutterson (formerly of DNA Plant Technology), Susan Harlander (BioRational Consultants), Kathy Means (Produce Marketing Association), Irvin Mettler (formerly of Seminis Vegetable Seeds), Carlos Reyes (Monsanto), Chuck Rivara (California Tomato Research Institute), David Schmidt (International Food Information Council), Terry Stone (Monsanto), Larry Stults (Syngenta) and Mary Zischke (Dole Fresh Vegetables). 
be additional environmental costs and benefits to take into account as an element of national costs and benefits. For instance, pest-resistant crops can reduce the application of broad-spectrum chemical pesticides, which are hazardous to farmworkers, compromise food safety and impose a burden on the environment. The economic studies to date have not assessed these environmental costs and benefits. However, Gianessi et al. (2002) estimated that adoption of the eight current cultivars allowed a reduction in pesticide use of 46 million pounds in 2001, and the 32 potential cultivars could have allowed a further reduction of 117 million pounds. The relevant comparison then is between the environmental risks associated with these biotech crops and those associated with the annual burden on the environment of 163 million pounds of chemical pesticides that could be avoided by growing biotech crops instead - 66 million pounds in California alone, where 185.5 million pounds of pesticides were used in 1999 (Mullen et al. 2003)

Market acceptance. On the demand side, farmers will adopt biotech varieties if the perceived net benefits to them are large enough, and this depends on the perceived market acceptance of GM crops. Concerns have been raised about the possibility that GM crops may be unsafe for consumers because of allergens or other, as yet unidentified risk factors, about risks to the environment and to the economy from uncontrolled genetic drift, and about the moral ethics of tampering with nature. The GM varieties that have been developed and adopted extensively to date have not experienced significant price discounts because of buyer resistance. This can probably be attributed to the nature of the crops. For feed grains, the buyers are other farmers who are comfortable with the technology, and for fiber crops such as cotton the food safety concerns do not apply. For the major food grains, wheat and rice, even if the farmproduction economics potential of GM varieties is as large as for feed grains, market acceptance may differ sufficiently to limit their adoption. Rather

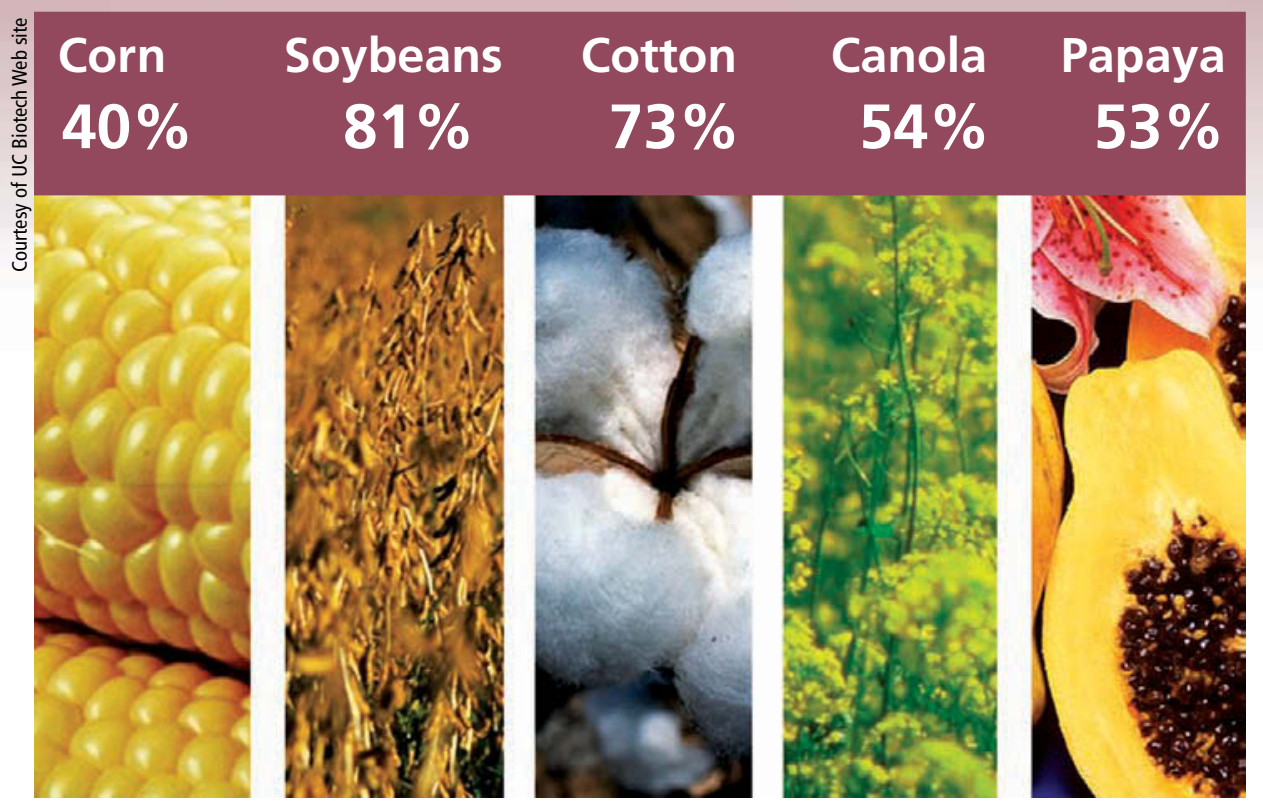

Significant percentages of acres planted to major U.S. row crops and one minor horticultural crop (papaya) were genetically engineered varieties in 2002 (canola) and 2003. These crops were transformed to provide traits attractive to growers rather than consumer-oriented traits like taste or nutritional value.

than another farmer, the relevant buyer for these crops is a food processor, manufacturer or retailer who may be reluctant to risk negative publicity or to risk losing consumers who would prefer a biotech-free label or who may not be confident that the biotech and nonbiotech grain can be segregated.

Processors and retailers. It is not sufficient that farmers and consumers perceive net benefits from GM crop varieties. The adoption of biotechnology must provide net benefits to other participants in the marketing chain, such as food processors and retailers. Pricing of the technology may be a critical factor. Even if the new technology is more cost-effective than the traditional alternative, monopolistic pricing could mean that the technology supplier retains a large share of the benefits. The cost savings passed on to processors and consumers may be a small fraction of the total benefits, rendering incentives for processors, retailers and consumers to accept the technology comparatively small. Processors and retailers can effectively block a new technology if it does not clearly benefit them, even if there would be net benefits to the general public.

Fixed costs. The size of the market matters. The cost to develop a new variety is essentially the same whether it is adopted on one acre or a million acres, but the benefits are directly pro- portional to the number of acres on which the variety is adopted. This is why biotech companies have focused on developing technologies for more widely planted agronomic crops, especially feed-grain and fiber crops for which market barriers are lower.

The technology developer must also obtain regulatory approvals. It is difficult to obtain precise information on costs of regulatory approval for biotech crops and chemical pesticides, but according to available estimates, the total cost of R\&D - from "discovery" to commercial release of a single new pesticide or herbicide product - exceeds $\$ 100$ million, and regulatory approval alone costs more than $\$ 10$ million. A new technology must generate enough revenue for the developer over its lifetime to cover these costs, and for some crops the total acreage is simply not sufficient. Given the large fixed costs associated with regulatory approvals for specific uses, agricultural chemical companies have concluded that the potential market is too small to warrant the development of pesticides for many of California's specialty crops, which have become technological orphans.

It does not follow that the government should invest in developing new conventional or GM pest-control technologies for these orphan crops. If the current regulatory policy and process is appropriate and efficiently 
implemented then the high cost is not excessive; if a new technology cannot generate benefits sufficient to pay those costs, then it is simply not economical to develop that technology. The question for technology orphan crops is whether it is possible to reduce the costs of R\&D and regulatory approval sufficiently to make it profitable for the nation and the private sector to change their orphan status.

\section{Markets for horticultural biotech}

On the supply side, "horticulture" includes an enormous diversity of fruit and vegetable crops, but it also includes many nonfood species, such as ornamentals, flowers and recreational turfgrass. Collectively these horticultural crops compare well with major agronomic crops in terms of total value in the United States. However, they use much less acreage, and the market size for some biotech products depends on both acreage and production value. In 2000, the United States produced fruits, nuts and vegetables with a total value of more than $\$ 28$ billion, of which California contributed about $\$ 14$ billion (table 1 ). In addition, horticulture includes a small number of larger-scale crops (such as potatoes and onions, apples and wine grapes) as well as a large number of smaller-scale crops (such as Brussels sprouts and persimmons). At current costs for R\&D and regulatory approval, it is unlikely that biotechnology products will be developed and achieve market acceptance for many of these smaller-scale crops in the near future (see sidebar, page 84). Further, experimentation with perennials such as grapes, nuts and fruit trees is comparatively expensive (because the experimental unit is larger and takes more time), and it is costly to bring new acreage into production or replace an existing vineyard or orchard with a new variety.

On the demand side, the market for horticultural products, especially fresh fruits and vegetables, is undergoing important changes associated with the changing structure of the global food industry (see sidebar, page 82). Increasingly fewer and larger supermarket chains have been taking over the global market for fruits and vegetables, especially fresh produce, and changing the way these products are marketed. Because fresh produce is perishable and subject to fluctuations in availability, quality and price, it presents special problems for supermarket managers compared with packaged goods. Supply-chain management, and the increasing use of contracts that specify production parameters as well as characteristics and price, is replacing spot markets for many fresh products. A desire for standardized products, regard- less of where they are sourced around the world, could limit the development and adoption of products targeting smaller market segments, unless retailers perceive benefits and provide shelf space for diversified products - such as biotech and nonbiotech varieties of particular fruits and vegetables.

On the other hand, an increasingly wealthy and discriminating consuming public can be expected to continue to demand increasingly differentiated products - with an ever-evolving list of characteristics such as organic, lowfat, low-carbohydrate and farm-fresh. Hence retailers will have to balance the cost savings and convenience as-

\begin{tabular}{|c|c|c|c|c|c|}
\hline \multirow[b]{2}{*}{ Commodity } & \multicolumn{2}{|c|}{ Value of production } & \multicolumn{3}{|c|}{ Area grown } \\
\hline & California & U.S. & California & U.S. & World \\
\hline Fruits and tree nuts & \multicolumn{2}{|c|}{ million $\$$. } & \multicolumn{3}{|c|}{$\ldots \ldots \ldots$ thousands of acres $\ldots . \ldots$} \\
\hline Almond & 655 & 655 & 500 & 500 & 4,136 \\
\hline Apple & 142 & 1,326 & 31 & 445 & 13,517 \\
\hline Apricot & 27 & 32 & 19 & 20 & 951 \\
\hline Avocado & 310 & 326 & 59 & 65 & 827 \\
\hline Grapefruit & 55 & 285 & 15 & 145 & 620 \\
\hline Grape, all types & 2,804 & 3,072 & 827 & 946 & 18,503 \\
\hline Kiwi & 14 & 14 & 5 & 5 & 136 \\
\hline Orange & 514 & 1,683 & 196 & 815 & 8,930 \\
\hline Peach/nectarine & 358 & 595 & 103 & 191 & 5,114 \\
\hline Strawberry & 840 & 1,086 & 28 & 48 & 575 \\
\hline Total* & 7,285 & 12,626 & 2,464 & 4,092 & NA \\
\hline \multicolumn{6}{|c|}{ Vegetables and melons } \\
\hline Artichoke & 71 & 61 & 9 & 9 & 307 \\
\hline Asparagus & 144 & 221 & 37 & 77 & 2,645 \\
\hline Bell pepper & 172 & 527 & 21 & 62 & 969 \\
\hline Carrot & 322 & 438 & 85 & 123 & 2,357 \\
\hline Cauliflower & 212 & 249 & 42 & 47 & 2,259 \\
\hline Garlic & 140 & 155 & 29 & 35 & 2,660 \\
\hline Lettuce & 1,581 & 1,872 & 211 & 284 & 2,079 \\
\hline Melon & 372 & 704 & 90 & 290 & 10,175 \\
\hline Onion & 189 & 736 & 50 & 166 & 557 \\
\hline Potato & 209 & 2,591 & 44 & 1,348 & 49,490 \\
\hline Tomato & 948 & 1,809 & 311 & 432 & 9,745 \\
\hline Total* & 6,718 & 15,560 & 1,734 & 2,820 & NA \\
\hline \multicolumn{6}{|l|}{ Field crops } \\
\hline Corn for grain & 65 & 18,499 & 205 & 72,440 & 340,580 \\
\hline Cotton & 807 & 4,260 & 914 & 13,053 & 82,000 \\
\hline Rice & 217 & 1,050 & 548 & 3,039 & 380,019 \\
\hline Soybeans & 0 & 12,467 & 0 & 72,408 & 183,804 \\
\hline Wheat & 104 & 5,782 & 487 & 53,133 & 532,545 \\
\hline Total* & 1,586 & 47,514 & 4,738 & 328,449 & NA \\
\hline
\end{tabular}

*Totals include many other crops in addition to those listed.

NA = not available.

Sources: USDA National Agricultural Statistical Service and California Agricultural Statistics Service for California and U.S. data; United Nations Food and Agricultural Organization for world data; Cotton Incorporated for world acreage of cotton. 
Supporters of agricultural biotechnology believe it can help to reduce pesticide use and provide more abundant food for an everincreasing global population. Government can play a role in guaranteeing safety while ensuring that unreasonable hurdles are not preventing its broader distribution. Far right, aerial spraying of pesticides; right, a produce market in Ethiopia.

sociated with global standardization against the benefits from providing a greater range of products, which will include GM products when retailers begin to perceive benefits from stocking them. Unlike other types of foods, fruits and vegetables are often consumed fresh and in clearly identifiable and recognizable form. This has implications for perceptions of quality and food safety that may influence consumer acceptance - perhaps favorably, for instance, if a genetically modified sweet-corn could be marketed as reduced-pesticide (see page 99).

Other elements of GM horticulture - such as nonfood products, ornamentals or turfgrass - have advantages in terms of potential market acceptance. GM trap crops, which provide pesticide protection for other crops, and GM sentinel crops, which signal the presence of pests or provide other agronomic indicators - may be used in food production without overcoming barriers of acceptability to market middlemen or consumers (see page 89). Biotechnology products designed for home gardeners may be more readily accepted because the grower is the final consumer.

Market acceptance in the United States is also linked to continued access to export markets, particularly in the European Union and Japan where restrictions have been applied to biotech foods. The relative importance of the domestic market could help to account for the success of the GM feed-grain technologies in the United States, and it may also help to account for the success of these and other GM technologies in China. China is comparatively important in horticultural biotechnology - its investment in agricultural biotechnology is second only to the United States, but with a different emphasis, including significant investment in horticultural biotechnology (see page 112).
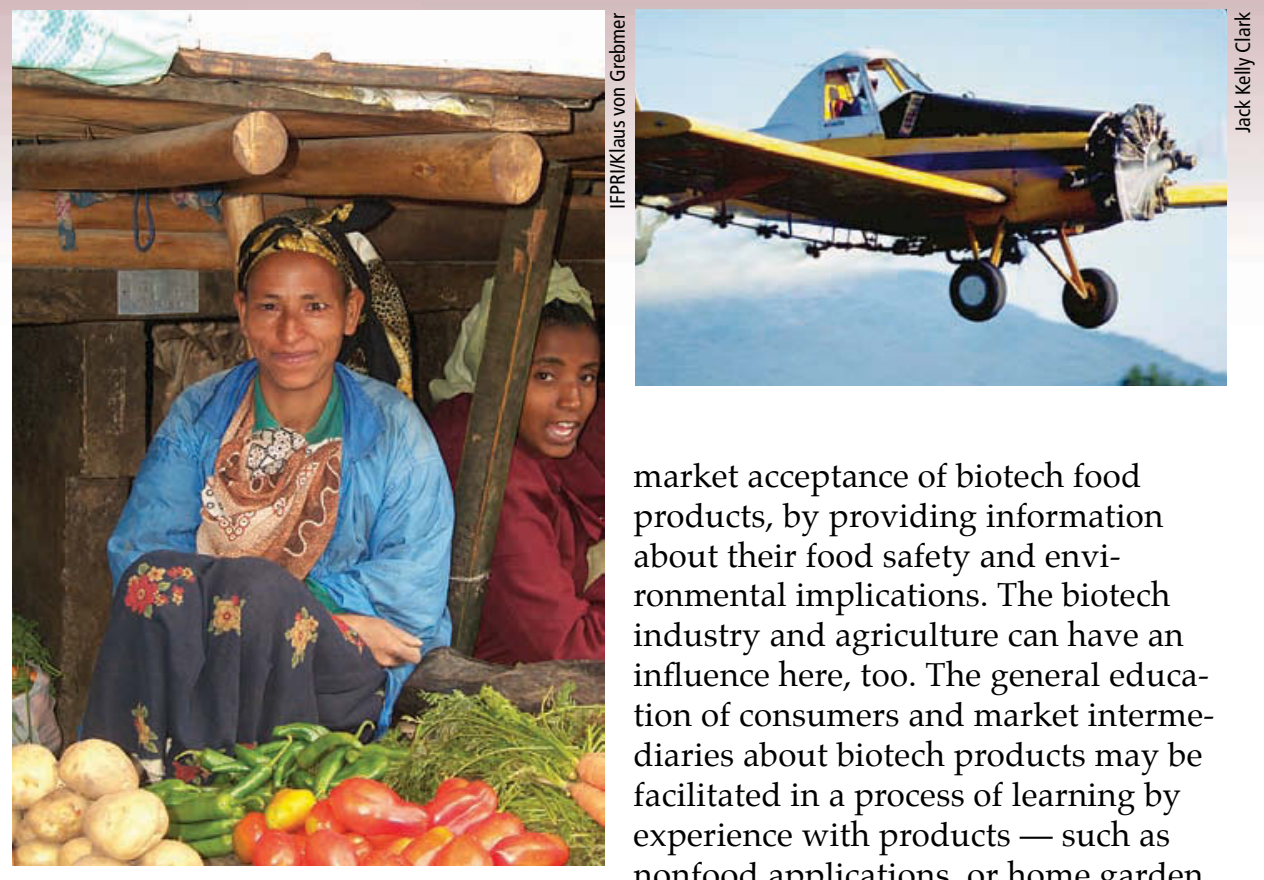

\section{Implications for government policy}

The technological potential for GM horticultural crops appears great, particularly when we look beyond the "input" traits that have dominated commercial applications to date, to opportunities in "output" traits, such as pharmaceuticals and shelf-life enhancements. Because delays in socially beneficial technologies mean forgone benefits, there may be a legitimate role for the government in facilitating a faster rate of development and adoption of horticultural biotechnology products. For instance, the government could reform property-rights institutions to increase efficiency and reduce $R \& D$ costs. IPRs apply to research processes as well as products, and limited access to enabling technology or simply the high cost of identifying all of the relevant parties and negotiating with them, may be retarding some lines of research - a type of technological gridlock (Binenbaum et al. 2003). Nottenburg et al. (2002) suggest a government role in improving access to enabling technologies. Similarly, the government could revise its regulations to increase efficiency and reduce costs for regulatory approvals. Instead of requiring a completely separate approval for each genetic transformation "event," it may be feasible to approve classes of technologies with more modest specific requirements for individual varieties.

The government could also reduce some barriers to adoption, especially

\section{J.M. Alston is Professor, Department of} Agricultural and Resource Economics, UC Davis, and Associate Director for Science and Technology Policy, UC Agricultural Issues Center.

\section{References}

Alston JM, Chan-Kang C, Marra MC, et al. 2000. A Meta-Analysis of the Rates of Return to Agricultural R\&D: Ex Pede Herculem. IFPRI Research Rep No 113. Washington, DC: International Food Policy Research Institute.

Binenbaum E, Nottenburg C, Pardey PG, et al. 2003. South-North trade, intellectual property jurisdictions, and freedom to operate in agricultural research on staple crops. Econ Devel Cultural Change 51(2):309-36.

Gianessi LP, Silvers CS, Sankula S, Carpenter JE. 2002. Plant Biotechnology: Current and Potential Impact for Improving Pest Management in U.S. Agriculture; An Analysis of 40 Case Studies. Washington, DC: National Center for Food and Agricultural Policy. www.ncfap.org.

James C. 2000. Global Review of Transgenic Crops: 2000. ISAAA Brief No 23. Ithaca, NY. www.agbiotechnet.com.

Mullen JD, Alston JM, Sumner DA, et al. 2003. Returns to University of California Pest Management Research and Extension: Overview and Case Studies. ANR Pub 3482, Oakland, CA.

Nottenburg C, Pardey PG, Wright BD. 2002. Accessing other people's technology for non-profit research. Australian J Ag Resource Econ 48(3):389-416. 